\title{
Social Movement, a Catalyst to Social Development and Change: A Case Study of Hadejia Ina Mafita Initiative
}

\author{
Hussaini Shehu \\ Department of Sociology, Lovely Professional University, Phagwara, Punjab, India \\ Department of Social Administration, Jigawa State Polytechnic, Dutse Nigeria
}

How to cite this paper: Shehu, H. (2018).
Social Movement, a Catalyst to Social De-
velopment and Change: A Case Study of
Hadejia Ina Mafita Initiative. The Education-
al Review, USA, 2(11), 535-554.
http://dx.doi.org/10.26855/er.2018.11.004

Corresponding author: Hussaini Shehu, Degree, Department of Sociology, Lovely Professional University, Phagwara, Punjab, India; Department of Social Administration, Jigawa State Polytechnic, Dutse Nigeria.

\begin{abstract}
Hadejia Ina Mafita Initiative (HIMI) Social movements have done a lot in bringing the desired social development and change in the marginalized North-East Zone of Jigawa State, Nigeria. Their activities as community-based organizations helped to bridge the existing gap in the redistribution of developmental projects between the three senatorial zones of the state as enshrined in the Nigerian constitution. The movement started with public awareness lecture through the Internet and social media platform (Facebook), letter engaged in the outreached public sensitization, awareness campaigns lectures on problems the zone is suffering from, and the need to find a solution to the problems identified. This paper examines the emergence of HIMI, the role played by them in bringing the development closer to their people. They act as a third sector between the government on one side and the community on the other side. People grievances are channelled through them. The paper elucidates the visible and tangible development realized by initiative across the area they operate and other parts of the state. The paper recommends that, instead of the violent struggle that may lead to civil unrest. The other related social movements should adopt 'Hadejia Ina Mafita's' pattern. They tackle their problems through endurance and educative approach, and the uneven distribution pattern they realize their zone is suffering and seems to gradually diminish. Through their efforts balance development is adopted by the government hence so many achievements have been recorded within the shortest time. The paper covers the introduction, the definitions of concepts, historical overview of HIMI, Objectives of the movement, Uses of the Social Media by HIMI Movement, and how their objectives are achieved.
\end{abstract}

\section{Keywords}

Social Movements, Social Development, Civil Society Organizations, Hadejia Ina Mafita Initiative, Balance Development

\section{Introduction}

Social movements are developmental tools globally. They assist in areas like helping the citizenry from oppression by governments, unequal distribution of resource, marginalization, and many more. The social movement encourages members of the group in striving towards the equitable redistribution and the spread of any resource across nations, States, as well as Communities. People decided to form civil society organizations and social movements when they feel marginalized, suffers from social exclusion, relatively deprived to enjoy equal rights opportunities and privileges as accorded to other citizens and segregat- 
ed from the rest of the state (Ahmed, 2017). They tend to organize themselves in order to strive for the solution to this social problem. Social movements can be defined as "organizational structures and strategies that may empower oppressed populations to mount effective challenges and resist the more powerful and advantaged elites" (Glasberg, \& Shannon, 2011).

Social movements are purposeful, organized groups, either with the goal of pushing toward change, giving political voice to those without it, or gathering for some other common purpose (Little, 2014). Social movements are purposeful, organized groups striving to work toward a common social goal. In Nigeria, the distribution of resources across the nation seems to be lopsided in some states which are closely linked to marginalization and discrimination on the basis of religion, ethnicity, regionalism, and sectionalism hence there is the need of social movements so as to help address the anomalies. Some politicians and highly placed individuals in the country are in one way or the other bias when it comes to the execution of developmental projects and appointments. This problem leads to the emergence of many ethnic militias struggling for the liberation of their communities. Sometimes, the activities of these militias turn to violence and insurgency (Tersoo \& Ejue, 2015). Meanwhile, this approach adopted by the militias to solve the grievances of their people are perceived by HIMI as a social problem and therefore initiated a new nonviolent way. This paper reviews the activities of Hadejia Ina Mafita Initiative, its objectives and how they strive and achieved them. The paper suggests that HIMI strategist should be adopted by similar social movements, civil societies and community-based organizations in pursuit of egalitarianism and balanced development of their regions. It comprises the introduction, the Conceptual Definitions, the historical overview of HIMI; the Objectives of the movement, the uses of Social Media, How HIMI was able to achieve its objectives of ensuring balanced development across the state, the voluntary educational training programs rendered by the movement, Youth and Women Empowerment through Skills Acquisitions. Additionally, the essay draws a conclusion and recommendations.

\section{Conceptual Definitions}

\subsection{Social Movement}

The term social movement came into being in 1850 by a renowned German Sociologist Lorenz von Stein as clearly stated in his book titled, History of France from 1789 to the Present. Social movements can be defined as "organizational structures and strategies that may empower oppressed populations to mount effective challenges and resist the more powerful and advantaged elites" (Glasberg, \& Shannon, 2011). In a related literature, Charles Tilly defines Social Movements as a series of contentious performances, displays, and campaigns by which ordinary people made collective claims on others (Tillay, 2004). According to Tilly, "social movements are a major vehicle for ordinary people's participation in public politics".

A social movement is a "collective challenges to elites, authorities, other groups or cultural codes by people with common purposes and solidarity in sustained interactions with elites, opponents, and authorities." He specifically distinguishes social movements from political parties and interest groups (Sidney, 2005). A social movement consists of a number of people organized and coordinated to achieve some task or a collection of goals, often the participants are interested in bringing about social change. Compared to other forms of collective behavior, movements have a high degree of organization and are of longer duration.

\subsection{Social Development}

Social development is about putting people at the center of development. This means a commitment that development processes need to benefit people who are poor and how they interact in groups and societies, including the norms that facilitate such interaction (Gloria, 2004). United Nations Research Institute for Social Development UNRISD (2011), defined Social development as a "processes of change that lead to improvements in human well-being, social relations, and social institutions, and that are equitable, sustainable, and compatible with principles of democratic governance and social justice". Midgley 
(2014), defined social development here "as a process of planned social change designed to promote the well-being of the whole population as a whole within the context of a dynamic multifaceted development process".

\subsection{Civil Society Organizations (CSOs)}

According to 2007-2008 Advisory Group on Civil society organizations and Aid Effectiveness CSOs: Can be defined to include all non-market and non-state organizations outside of the family in which people organize themselves to pursue shared interests in the public domain. Examples include community-based organizations and village associations, environmental groups, women's rights groups, farmers' associations, faith-based organizations, labour unions, co-operatives, professional associations, chambers of commerce, independent research institutes and the not-for-profit media (2008: 7).

Civil society organizations "are voluntary organizations with governance and direction coming from citizens or constituency members, without significant government-controlled participation or representation” (2008: 9).

\subsection{Community-Based Organization (CBO)}

A Community Based Organization (CBO) "is an organization that provides social services at the local level. It is a non-profit organization whose activities are based primarily on volunteer efforts. This means that CBOs depend heavily on voluntary contributions for labor, material, and financial support"(Chechetto-Salles \& Geyer, 2006:4).

\subsection{Hadejia Ina Mafita Initiative (HIMI):}

Hadejia Ina Mafita Initiative is a nongovernmental, nonpolitical, community based organization, basically a social movement in North east Senatorial Zone of Jigawa State, Nigeria (Hadejia Emirate). HIMI means 'Hadejia Which Way Out' literally, and serving the 8 Local Government Areas of the emirate. The membership of organization comprises the people living within Hadejia Emirate, outside the state and those Hadejians living overseas. It was founded in 2011 but formally registered as CBOs on 7th December 2015 by the Corporate Affairs Commission of the Federal Republic of Nigeria. "Its activities cover general service delivery and serving as the common voice of the people" (Ahmed, 2017). HIMI has five organs: Executives, Think Tank, Grand Patron, Patrons, and Special consideration for women.

\subsubsection{Vision and Mission}

\section{Vision}

Create a supportive, sustainable and collaborative platform to strengthen unity and co-operation to address the challenges by reaching all, irrespective of socio-economic status, political affiliation or another factor.

\section{Mission}

The mission of HIMI is Promoting economic, social, cultural, political and environmental progress across Hadejia Senatorial District and Jigawa state at large by reconciling our need with the need of others.

\section{The Historical Overview on the Emergence of Hadejia Ina Mafita Initiative}

HIMI is a nonprofit, nongovernmental and nonpolitical community based organization/ Social movement situated in Hadejia Senatorial District of Jigawa state, Nigeria which comprises eight local governments' areas of Hadejia emirate. The local governments are Auyo, Birniwa, Guri, Hadejia, Kafin Hausa, Kaugama, Kiri kassamma and Malammadori LGAs. The movement was formed and started its activities in 2011 on social media via a Facebook flat form with 6,886 registered online members (Ahmed, 2017). The sole aim of the movement is to bring unity and a sense of brotherhood and togetherness among the entire people of Hadejia senatorial zone. Similarly, to find solutions to the problems of deeply rooted social exclusion the zone is suf- 
fering for many years without a solution. They do so by identifying the social, political and infrastructural development problems affecting the zone with the hope of enlightening people how to overcome and arrest the situation. The movement engages in strategic weekly online conference to sensitizing the people on the issues bedeviling progress and development of the zone: social integration and unity for the development of the zone, drug abuse among youth, impact of Fulani Pastoralist-farmers conflict, sexual abuse of minors, balanced development across the state and the nation at large, and sensitizing people to know their constitutional rights among others.

The group started a public sensitization lecture across the eight Local Government Areas (LGAs) of the zone in 2013. By 2015 the movement covered all the 8 LGAs of the emirate and extended the enlightenment to cover so many districts. It becomes a formally registered community based organization on 7th December 2015, by the Corporate Affairs Commission of the Federal Republic of Nigeria (HIMI Constitution, 2014). The popular slogan of the movement is that, 'Only when United the Desired Change will come'. The movement claims that since Nigeria's independence, Hadejia Emirate has been unfairly treated and marginalized in the distribution of developmental projects, appointments, and other infrastructural facilities levelled as necessities of lives. Again, HIMI claims that the Emirate is among the few senatorial zones that are not participating in the national unity as a result of the absence of Federal Government Unity Colleges, Federal Educational, and Health institutions in the zone. According to HIMI once more, there is no inclusive development and growth in the execution of state projects among the three Senatorial Districts of Jigawa state. The distribution seems lopsided which is contrary to what is enshrined in the constitution of the Federal Republic of Nigeria, the Federal Character Commission and the Jigawa State law which allow equitable distribution of developmental projects across the three senatorial districts (The Law of Jigawa State, 2012).

\section{Objectives of the HIMI}

The following are the objectives of the movement:

1. To identify the problems affecting Jigawa North-east Senatorial District

2. To diverse possible means and measures of solving or curtailing the problems

3. To liaise with other sister organizations from within and other emirates, and senatorial districts in order to achieve unity and peace in Jigawa state and Nigeria in general

4. 4. To develop strategist through partnering with the government and nongovernmental organizations (NGOs) in order to achieve their goals.

\section{Uses of the Social Media by HIMI Movement}

The movement started its public awareness campaign through the Internet and social media Facebook platform as a close group with members who were strictly sons and daughters of the zone. This initiative appears similar to Obar, Zube, and Lampe (2012) who postulated that "Modern movements often utilize technology and the internet to mobilize people globally. Adapting to communication trends is a common theme among successful movements" (Obar, Zube, \& Lampe, 2012). Just like any other global social movement, Ina Mafita realizes that social media is paramount for the survival of their struggles. According to Clark (2012), Social movements need the mainstream media for several purposes, such as;

Struggling for defining certain issues and states of affairs as social problem and demanding social and political changes to solve the problems, analyzing causes of and suggesting solutions to social problems, challenging and pressuring adversaries and political decision-makers, constructing and maintaining the collective identity of a movement or a group and thereby constructing an imagined community for activists to identify themselves with and to have a sense of belonging, analyzing causes of and suggesting solutions to social problems, influencing the public opinion, seeking for support and sympathy for the cause.

In its bid toward public awareness and sensitization on the perceived marginalization of their constituency and people, HIMI 
uses Internet and Facebook platform to mobilize people on the need to have a unanimous voice on who is best to be voted to govern the state who would balance the asserted anomalies they claimed to have existed in the state. The movement adopted the above strategy to identify problems and suggest achieving them by uniting the entire people of the zone irrespective of their political differences through the preaching of unity. To the movement, a journey toward success could be achieved when the entire zone unites themselves and speaks with one voice. The unity that was realized among the people of the zone motivated HIMI and was able to articulate their claims. They were able to gather facts and figures including statistical analysis regarding the lopsided developmental projects to be executed across the three senatorial districts. These projects were roads network, educational institutions (both Federal and State), health institutions and how they are shared or located across the three senatorial zones as illustrated below.

\section{How Do They Achieve Their Objectives?}

According to the HIMI spoke man Shehu (2018, June 14) HIMIs dreams came true when the movement realizes that all the identified problems occurred due to lack of proper political agreement between the people of the emirate and the government concerned. HIMI humbly appealed to the present leadership of the state to consider the zone's aspiration for a 'balanced development across the three zones' of the state. The comparative analysis of the infrastructural projects executed within the state by the past governments was carefully made by HIMI and presented to the government as shown in Table 1 below. In doing so, the movement hopes that the government would balance the lopsided development identified. Fortunately, from 2015 to date, many unattended development projects tabled to the government have been successfully executed. The New Comparative Analysis of Infrastructural Development within the three (3) Senatorial Zones of Jigawa state as of October 2018 is shown in Table 2 and pictures below. The charts are also presented for easy comparison in the attached appendix.

Table 1. Comparative analysis of infrastructural development within the three (3) senatorial zones of Jigawa State, Nigeria as at, 2015.

\begin{tabular}{|c|c|c|c|}
\hline \multicolumn{4}{|c|}{ Spread of the Projects to each Senatorial District Across the State } \\
\hline & Jigawa Central (Dutse) & Jigawa Northwest (Kazaure) & $\begin{array}{l}\text { Jigawa Northeast (Hadejia) } \\
\end{array}$ \\
\hline & $\begin{array}{l}\text { This zone has seven (7) Local } \\
\text { Government Areas }\end{array}$ & $\begin{array}{l}\text { This zone has twelve (12) Local Gov- } \\
\text { ernment Areas }\end{array}$ & $\begin{array}{l}\text { This zone has eight (8) Local Government } \\
\text { Areas }\end{array}$ \\
\hline \multirow[t]{2}{*}{ Roads } & $\begin{array}{l}\text { Township Roads: } \\
\text { 1. All the Local Govern- } \\
\text { ment Headquarters have } \\
\text { tarred roads with ex- } \\
\text { ception of Jahun Local } \\
\text { Government. }\end{array}$ & $\begin{array}{l}\text { Township Roads: } \\
\text { 1. All the Local Government } \\
\text { Headquarters have tarred roads } \\
\text { with exception of Kazaure, } \\
\text { Maigatari and Sule Tankarkar. }\end{array}$ & $\begin{array}{l}\text { Township Road } \\
\text { 1. Only three (3) Local Government } \\
\text { Headquarters have tarred roads in } \\
\text { the area and the following LGAs } \\
\text { are not tarred: } \\
\text { - Guri } \\
\text { - Hadejia } \\
\text { - Kafin Hausa } \\
\text { - Kaugama } \\
\text { - Mallam Madori }\end{array}$ \\
\hline & $\begin{array}{l}\text { State Roads: } \\
\text { 1. Roads linking various } \\
\text { villages/towns to the } \\
\text { Local Government } \\
\text { Headquarters were ei- } \\
\text { ther constructed, reno- } \\
\text { vated or rehabilitated. }\end{array}$ & $\begin{array}{l}\text { State Roads: } \\
\text { 1. Roads linking various villag- } \\
\text { es/towns to the Local Govern- } \\
\text { ment Headquarters were either } \\
\text { constructed, renovated or reha- } \\
\text { bilitated. }\end{array}$ & $\begin{array}{l}\text { State Roads: } \\
\text { The following roads are still waiting for } \\
\text { State Government attention: } \\
\text { 1. Kafin Hausa-Bulangu road via } \\
\text { Kwanar Dindu } \\
\text { 2. Garin Mutum Daya-Turabu road } \\
\text { 3. Yalleman-Kaugama road } \\
\text { 4. Hadejia-Guri road though reno- }\end{array}$ \\
\hline
\end{tabular}




\begin{tabular}{|c|c|c|c|}
\hline & & & $\begin{array}{l}\text { vated but now completely dilap- } \\
\text { idated. } \\
\text { 5. Kafin Hausa-Ruba-Balago road }\end{array}$ \\
\hline & $\begin{array}{l}\text { Federal Roads: } \\
\text { All the Federal highways in this } \\
\text { zone are renovated }\end{array}$ & $\begin{array}{l}\text { Federal Roads: } \\
\text { All the Federal highways in this zone are } \\
\text { renovated with exception of : } \\
\text { - Danbatta-Babura road } \\
\text { - Kano-Gumel-Hadejia road } \\
\text { - Gumel-Maigatari road }\end{array}$ & $\begin{array}{l}\text { Federal Roads: } \\
\text { The following road is waiting for Govern- } \\
\text { ment attention: } \\
\text { - Hadejia-Nguru road works stand } \\
\text { at stand-still around Birniwa } \\
\text { - Wudil-Gaya-Kafin Hausa-Zaki } \\
\text { highway completely dilapidated } \\
\text { - Hadejia-Gamayin-Bulangu-Azar } \\
\text { e Federal road completely aban- } \\
\text { doned since 1980. } \\
\text { - Kano-Gumel-Hadejia road }\end{array}$ \\
\hline $\begin{array}{l}\text { Health Insti- } \\
\text { tutions }\end{array}$ & 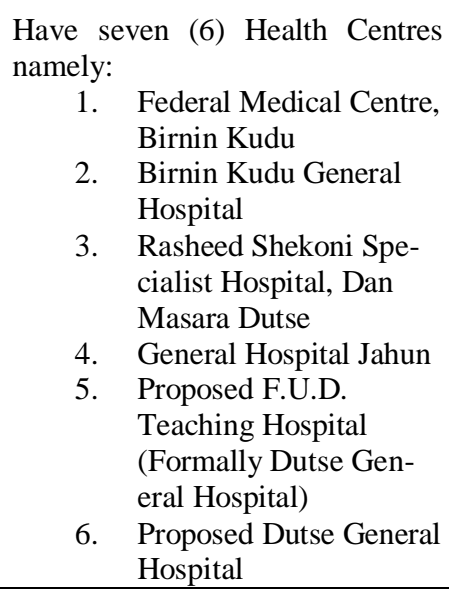 & $\begin{array}{l}\text { Have five (5) Hospitals. They are as fol- } \\
\text { lows: } \\
\begin{aligned} \text { 1. } & \text { General Hospital, Kazaure } \\
\text { 2. } & \text { General Hospital, Babura } \\
\text { 3. } & \text { General Hospital, Gumel } \\
\text { 4. } & \text { General Hospital, Ringim } \\
\text { 5. } & \text { Psychiatric Hospital, Kazaure }\end{aligned}\end{array}$ & $\begin{array}{l}\text { Have only one (1) General Hospital which } \\
\text { is situated in Hadejia town. }\end{array}$ \\
\hline $\begin{array}{l}\text { Tertiary In- } \\
\text { stitutions }\end{array}$ & \begin{tabular}{l} 
Have Six (6) Tertiary institu- \\
tions namely: \\
Federal Tertiary Institution \\
\multicolumn{1}{c}{ Federal University } \\
Dtate Tertiary Institution \\
1. $\quad \begin{array}{l}\text { College of Nursing and } \\
\text { Midwifery, Birnin Ku- }\end{array}$ \\
du \\
2. School of Health \\
Technology Jahun \\
3. Jigawa State Polytech- \\
nic, Dutse \\
4. National Open Univer- \\
sity, Dutae \\
5. National Teachers In- \\
stitute
\end{tabular} & $\begin{array}{l}\text { Have four (4) Tertiary institutions name- } \\
\text { ly: } \\
\text { Federal Tertiary Institution } \\
\\
\quad \text { Polytechnic, Kazaure } \\
\text { State Tertiary Institution } \\
\text { 1. Informatics Institute, Kazaure } \\
\text { 2. Jigawa State College of Educa- } \\
\text { tion, Gumel } \\
\text { 3. College of Legal \& Islamic } \\
\text { Studies, Ringim }\end{array}$ & $\begin{array}{l}\text { Have two (2) Tertiary Institutions } \\
\text { Federal Tertiary Institution } \\
\text { State Tertiary Institution } \\
\text { 1. Jigawa State University, Kafin } \\
\text { 2. Hausa } \\
\begin{array}{l}\text { Binyamin Usman College of Ag- } \\
\text { riculture, Hadejia (A } \\
\text { mono-technic) }\end{array}\end{array}$ \\
\hline $\begin{array}{l}\text { Federal Govt. } \\
\text { Unity Col- } \\
\text { leges }\end{array}$ & $\begin{array}{l}\text { Federal Government College, } \\
\text { Kiyawa }\end{array}$ & $\begin{array}{l}\text { Federal Government Girls College, } \\
\text { Kazaure }\end{array}$ & No any Federal College in the zone \\
\hline
\end{tabular}




\begin{tabular}{|c|c|c|c|}
\hline $\begin{array}{l}\text { Research } \\
\text { Institutions }\end{array}$ & $\begin{array}{l}\text { Federal Date/Oil palm Research } \\
\text { Institute, Dutse }\end{array}$ & Jigawa State Research Institute, Kazaure & Nil \\
\hline $\begin{array}{l}\text { Secondary } \\
\text { Schools }\end{array}$ & $\begin{array}{l}\text { Old Schools Fenced \& Reno- } \\
\text { vated: } \\
\text { All old Secondary Schools in this } \\
\text { zone were renovated and fenced. }\end{array}$ & $\begin{array}{l}\text { Old Schools Fenced \& Renovated: } \\
\text { All old Secondary Schools were renovat- } \\
\text { ed and fenced. }\end{array}$ & $\begin{array}{l}\text { Old Schools Fenced \& Renovated: } \\
\text { The following schools were partially reno- } \\
\text { vated without fencing: } \\
\text { 1. Government Secondary School, } \\
\text { Mallam Madori } \\
\text { 2. Government Secondary School } \\
\text { Wunti, Hadejia } \\
\text { 3. Government Technical College, } \\
\text { Hadejia } \\
\text { 4. Government Secondary School } \\
\text { Famfo Goma, Hadejia }\end{array}$ \\
\hline $\begin{array}{l}\text { JAMB Cen- } \\
\text { ters }\end{array}$ & $\begin{array}{l}\text { This zone has four (4) JAMB } \\
\text { centres namely: } \\
\text { 1. Jamb Office Dutse } \\
\text { 2. Isah Duniya Ba Hutu } \\
\text { (DBH) JAMB Centre, } \\
\text { Dutse } \\
\text { 3. Jigawa State Polytech- } \\
\text { nic Centre, Dutse } \\
\text { 4. Baimana Academy }\end{array}$ & 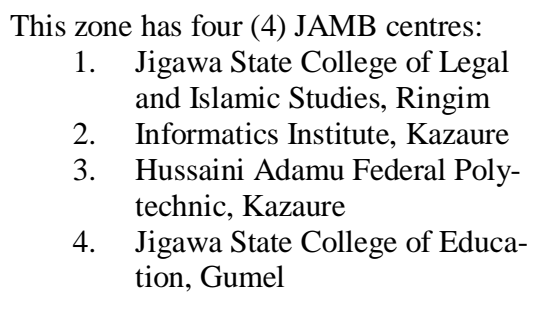 & No JAMB Centre (Nil) \\
\hline
\end{tabular}

Source: Field. A survey by Hadejia Ina Mafita

Table 2. Comparative Analysis of Infrastructural Development within the Three (3) Senatorial Zones of Jigawa State, Nigeria as at 2018.

\begin{tabular}{|c|c|c|c|}
\hline \multicolumn{4}{|c|}{ Spread of the Projects to each Senatorial District Across the State } \\
\hline & Jigawa Central (Dutse) & Jigawa Northwest (Kazaure) & Jigawa Northeast (Hadejia) \\
\hline & $\begin{array}{l}\text { This zone has seven (7) Local Govern- } \\
\text { ment Areas }\end{array}$ & $\begin{array}{l}\text { This zone has twelve (12) Local Gov- } \\
\text { ernment Areas }\end{array}$ & $\begin{array}{l}\text { This zone has eight (8) Local Gov- } \\
\text { ernment Areas }\end{array}$ \\
\hline \multirow[t]{3}{*}{ Roads } & $\begin{array}{l}\text { Township Roads: } \\
\text { All the Local Government Headquarters } \\
\text { have tarred roads including Jahun Local } \\
\text { Government }\end{array}$ & $\begin{array}{l}\text { Township Roads: } \\
\text { All the Local Government Headquarters } \\
\text { have tarred roads including Kazaure, } \\
\text { Maigatari and Sule Tankarkar }\end{array}$ & $\begin{array}{l}\text { Township Road } \\
\text { All the Local Govt. Headquarters now } \\
\text { have tarred roads in the area only } \\
\text { Kaugama LGA remain under con- } \\
\text { struction as at October } 2018\end{array}$ \\
\hline & $\begin{array}{l}\text { State Roads: } \\
\text { Roads linking various villages/towns to } \\
\text { the Local Government Headquarters } \\
\text { were either constructed, renovated or } \\
\text { rehabilitated }\end{array}$ & $\begin{array}{l}\text { State Roads: } \\
\text { Roads linking various villages/towns to } \\
\text { the Local Government Headquarters } \\
\text { were either constructed, renovated or } \\
\text { rehabilitated }\end{array}$ & $\begin{array}{l}\text { State Roads: } \\
\text { All roads linking various villag- } \\
\text { es/towns to the local government } \\
\text { Headquarters were construct- } \\
\text { ed/renovated except the following } \\
\text { roads: } \\
\text { Yalleman-Kaugama road (Not } \\
\text { considered) } \\
\text { Kafin Hausa-Ruba- Balago road }\end{array}$ \\
\hline & $\begin{array}{l}\text { Federal Roads: } \\
\text { All the Federal highways in this zone } \\
\text { are renovated }\end{array}$ & $\begin{array}{l}\text { Federal Roads: } \\
\text { All the Federal highways in this zone } \\
\text { are renovated with exception of: } \\
\text { Danbatta-Babura road } \\
\text { Kano-Gumel-Hadejia road }\end{array}$ & $\begin{array}{l}\text { Federal Roads: } \\
\text { The following road with the excep- } \\
\text { tion of Hadejia-Nguru road is waiting } \\
\text { for Government attention: } \\
\text { Wudil-Gaya-Kafin Hausa-Zaki }\end{array}$ \\
\hline
\end{tabular}




\begin{tabular}{|c|c|c|c|}
\hline & & Gumel-Maigatari road & $\begin{array}{l}\text { highway completely dilapidated } \\
\text { Hadejia-Gamayin-Bulangu-Azare } \\
\text { Federal road completely abandoned } \\
\text { since } 1980 \\
\text { Kano/Gumel/Hadejia road }\end{array}$ \\
\hline $\begin{array}{l}\text { Health } \\
\text { Institutions }\end{array}$ & $\begin{array}{l}\text { Have seven (7) Health Centers namely: } \\
\text { Federal Medical Centre, Birnin Kudu } \\
\text { Birnin Kudu General Hospital } \\
\text { General Hospital Gwaram (Under } \\
\text { construction) } \\
\text { Rasheed Shekoni Specialist (now } \\
\text { upgraded to F.U.D Teaching Hospi- } \\
\text { tal)Hospital, Dan Masara } \\
\text { General Hospital Jahun } \\
\text { Dutse General Hospital } \\
\text { New Gantsa Gen. Hospital (under } \\
\text { construction by the present administra- } \\
\text { tion) }\end{array}$ & $\begin{array}{l}\text { Have six (6) Hospitals. They are as } \\
\text { follows: } \\
\text { General Hospital, Kazaure } \\
\text { General Hospital, Babura } \\
\text { General Hospital, Gumel } \\
\text { General Hospital, Ringim } \\
\text { Kazaure Specialist Hospital (Under } \\
\text { construction) } \\
\text { New General Hospital at Garki (Under } \\
\text { construction by the present administra- } \\
\text { tion) }\end{array}$ & $\begin{array}{l}\text { Govt. has approved } 5 \text { additional } \\
\text { hospitals plus There already existing } \\
\text { one (1) Hadejia General Hospital now } \\
\text { six. They are: } \\
\text { Hadejia General Hospital } \\
\text { Hadejia Specialist Hospital ( } 70 \% \text {. } \\
\text { completion). } \\
\text { Upgraded Birniwa comp. health } \\
\text { centre to General Hospital } \\
\text { Upgraded Kafin Hausa comp. health } \\
\text { centre to General Hospital } \\
\text { Established Guri General Hospital } \\
\text { (Under construction) } \\
\text { Approved the construction of new } \\
\text { Malammadori Gen. Hospital (ap- } \\
\text { proved by state executive, in } 2018 \\
\text { Budget) }\end{array}$ \\
\hline $\begin{array}{l}\text { Tertiary } \\
\text { Institutions: }\end{array}$ & $\begin{array}{l}\text { Have six (6) Tertiary institutions } \\
\text { namely: } \\
\text { Federal Tertiary Institution } \\
\text { Federal University Dutse } \\
\text { State Tertiary Institutions } \\
\text { College of Nursing and Midwifery, } \\
\text { Birnin Kudu } \\
\text { School of Health Technology Jahun } \\
\text { Jigawa State Polytechnic, Dutse } \\
\text { National Open University, Dutae } \\
\text { National Teachers Institute }\end{array}$ & $\begin{array}{l}\text { Today Have six (6) Tertiary Institutions } \\
\text { namely: } \\
\text { Federal Tertiary Institution } \\
\text { Hussaini Adamu Federal } \\
\quad \text { Polytechnic, Kazaure } \\
\text { State Tertiary Institution } \\
\text { Informatics Institute, Kazaure } \\
\text { Jigawa State College of Education, } \\
\text { Gumel } \\
\text { College of Legal \& Islamic Studies, } \\
\text { Ringim } \\
\text { New School of Nursing at Babura } \\
\text { (Under construction by the present ad- } \\
\text { ministration) } \\
\text { New Jigawa State College of Art \& } \\
\text { Remedial Studies, Babura }\end{array}$ & $\begin{array}{l}\text { Now have Four Tertiary Institu- } \\
\text { tions } \\
\text { Federal Tertiary Institution } \\
\text { Nil? } \\
\text { State Tertiary Institution } \\
\text { Sule Lamido University (Formally } \\
\text { Jigawa State University, Kafin Hau- } \\
\text { sa) } \\
\text { Binyamin Usman College of } \\
\text { Agriculture, Hadejia (A } \\
\text { mono-technic), upgraded to Poly- } \\
\text { technic } \\
\text { Established New College of Nursing } \\
\text { and Midwifery at Hadejia } \\
\text { Granted a land for the Construction of } \\
\text { International Islamic University at } \\
\text { Hadejia }\end{array}$ \\
\hline $\begin{array}{l}\text { Federal } \\
\text { Govt. Unity } \\
\text { Colleges }\end{array}$ & Federal Government College, Kiyawa & $\begin{array}{l}\text { Federal Government Girls College, } \\
\text { Kazaure }\end{array}$ & No any Federal College in the zone \\
\hline $\begin{array}{l}\text { Research } \\
\text { Institutes }\end{array}$ & $\begin{array}{l}\text { Research Institute: } \\
\text { Federal Date/Oil palm Research Insti- } \\
\text { tute, Dutse }\end{array}$ & \begin{tabular}{l}
\multicolumn{3}{l}{ Research Institute: } \\
Jigawa State Research Institute, \\
Kazaure
\end{tabular} & $\begin{array}{l}\text { Research Institute: } \\
\text { Nil }\end{array}$ \\
\hline $\begin{array}{l}\text { Secondary } \\
\text { Schools }\end{array}$ & $\begin{array}{l}\text { Old Schools Fenced \& Renovated: } \\
\text { All old Secondary Schools in this zone } \\
\text { were renovated and fenced. }\end{array}$ & $\begin{array}{l}\text { Old Schools Fenced \& Renovated: } \\
\text { All old Secondary Schools were reno- } \\
\text { vated and fenced. }\end{array}$ & $\begin{array}{l}\text { Old Schools Fenced \& Renovated: } \\
\text { The following schools were partially } \\
\text { renovated without fencing: } \\
\text { Government Secondary School, } \\
\text { Mallam Madori } \\
\text { Government Secondary School }\end{array}$ \\
\hline
\end{tabular}




\begin{tabular}{|l|l|l|l|}
\hline & & & $\begin{array}{l}\text { Wunti, Hadejia } \\
\text { Government Technical College, } \\
\text { Hadejia } \\
\text { Government Secondary School } \\
\text { Famfo Goma, Hadejia }\end{array}$ \\
\hline $\begin{array}{l}\text { JAMB } \\
\text { Center }\end{array}$ & $\begin{array}{l}\text { This zone has 2 JAMB centres } \\
\text { Jamb Office Dutse }\end{array}$ & $\begin{array}{l}\text { This zone has four (4) JAMB centres: } \\
\text { Jigawa State College of Legal and } \\
\text { Islamic Studies, Ringim } \\
\text { Informatics Institute, Kazaure } \\
\text { Jigawa State Polytechnic Centre, Dutse } \\
\text { Kazaini Adamu Federal Polytechnic, } \\
\text { Tigawa State College of Education, } \\
\text { Gumel }\end{array}$ & $\begin{array}{l}\text { Tished } \\
\text { community leaders namely: } \\
\text { Binyamin Usman Polytechnic JAMB } \\
\text { Center, Hadejia and } \\
\text { Sule Lamido University JAMB } \\
\text { Center, Kafin Hausa }\end{array}$ \\
\hline
\end{tabular}

Source: Field Survey by Hadejia Ina Mafita Secretariat Nguru Road, Hadejia

In order to ensure the actualization of the project, HIMI adopted Tilly (2004) model called "WUNC displays: Participants' concerted public representation of worthiness, unity, numbers, and commitments on the part of themselves and/or their constituencies". HIMI show a remarkable commitment in order to encourage the government and to also ensure the project is executed successfully as promised by the government. HIMI made architectural design and bills of quantities (BQ) of the proposed Hadejia Specialist Hospital and that of College of Nursing and Midwifery and donate to the government as part of the contribution on behalf of the community. Additionally, the movement also participated in budget tracking and projects monitoring on all the projects been executed in the zone to ensure that due process is strictly adhered to.
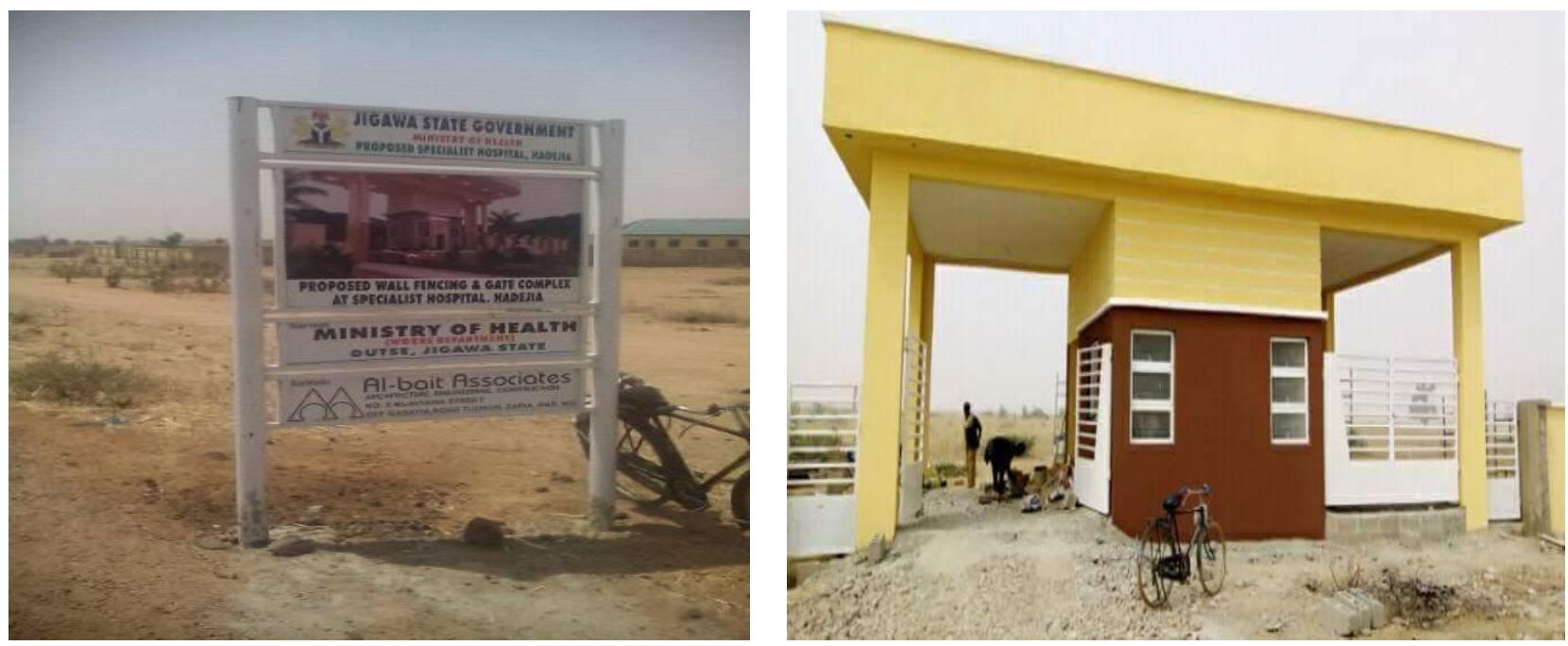

Figure 1. Proposed Hadejia specialist hospital under construction.

In relation to the lopsided health institutions across the three senatorial districts of the state, the Figure 1 above is a picture of Hadejia Specialist Hospital under construction which clearly shows that HIMI social movement has achieved its objective of having a befitting tertiary health institution in the zone. Similarly, another institution has also been established in another zone making a total number to three in the state.

The Figure 2 shows the newly established College of Nursing and Midwifery in Hadejia. According to HIMI originally the zone had this institution since early 1980 but was taken away by the first democratically elected Government to another zone. Due to their struggle, and in order to ensure balanced development across the state, two similar institutions were established making a total number of three in the state. 

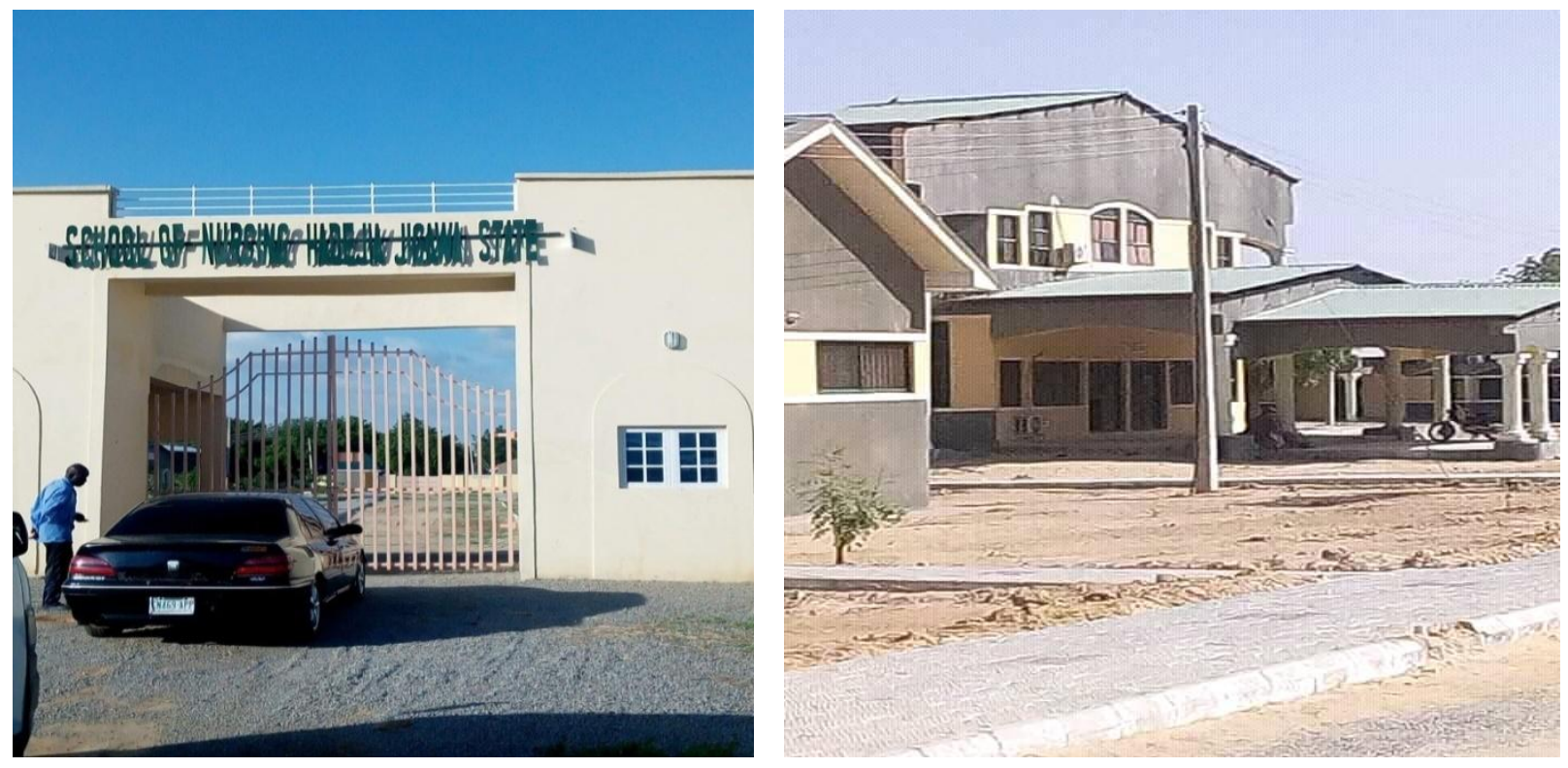

Figure 2. Entrance of new College of Nursing and Midwifery, Hadejia constructed by the present administration, established 2016.
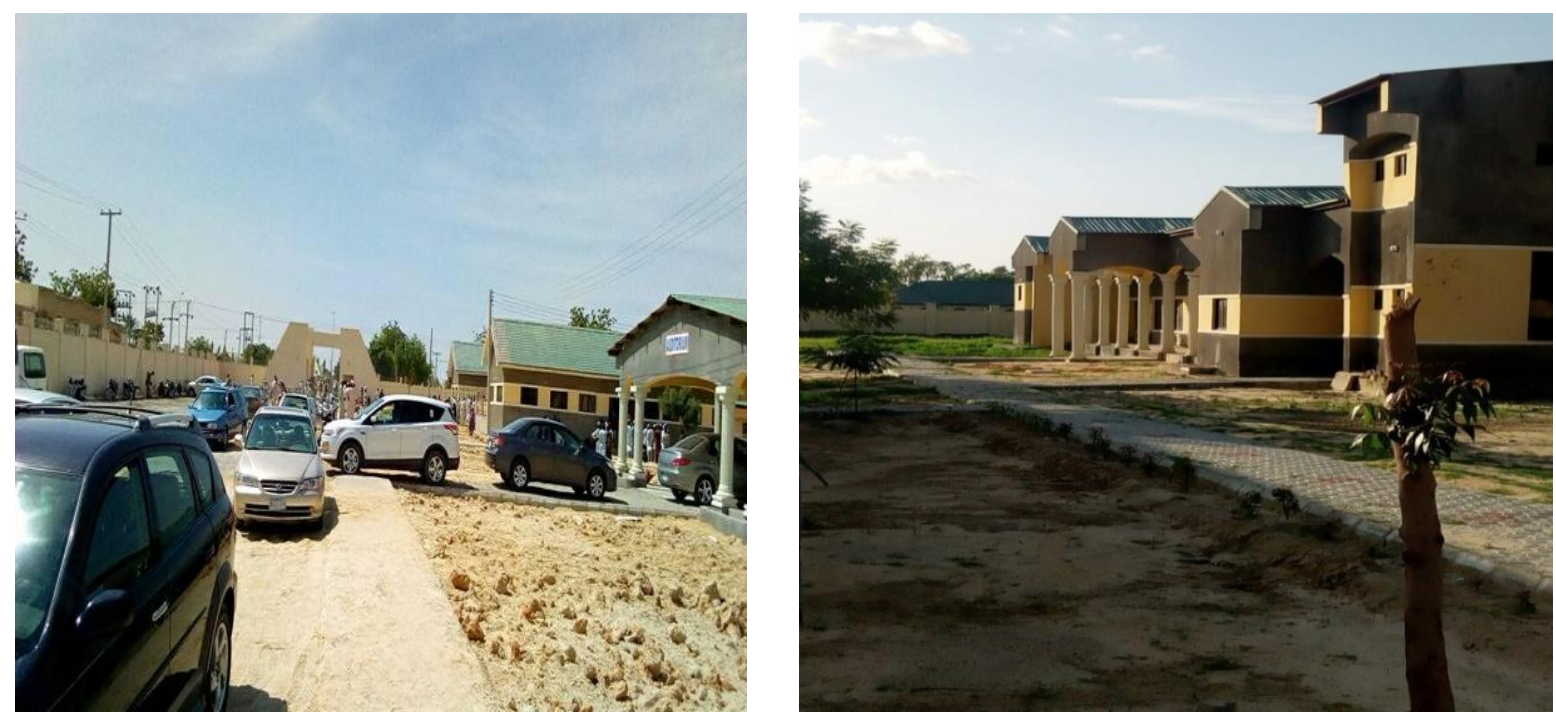

Figure 3. College of Nurse and Midwifery. Hadejia.

The pictures i.e. Figure 4 show a newly established Joint Admission and Matriculation Board Examination centre created in the zone at Hadejia city. The centre has 300 students carrying capacity. This center was also cancelled prior to HIMI struggles in early 2015.

The Figure 5 is one of the newly constructed Hadejia township roads which HIMI claimed that the previous government refused to construct despite been enlisted among the roads already constructed. 

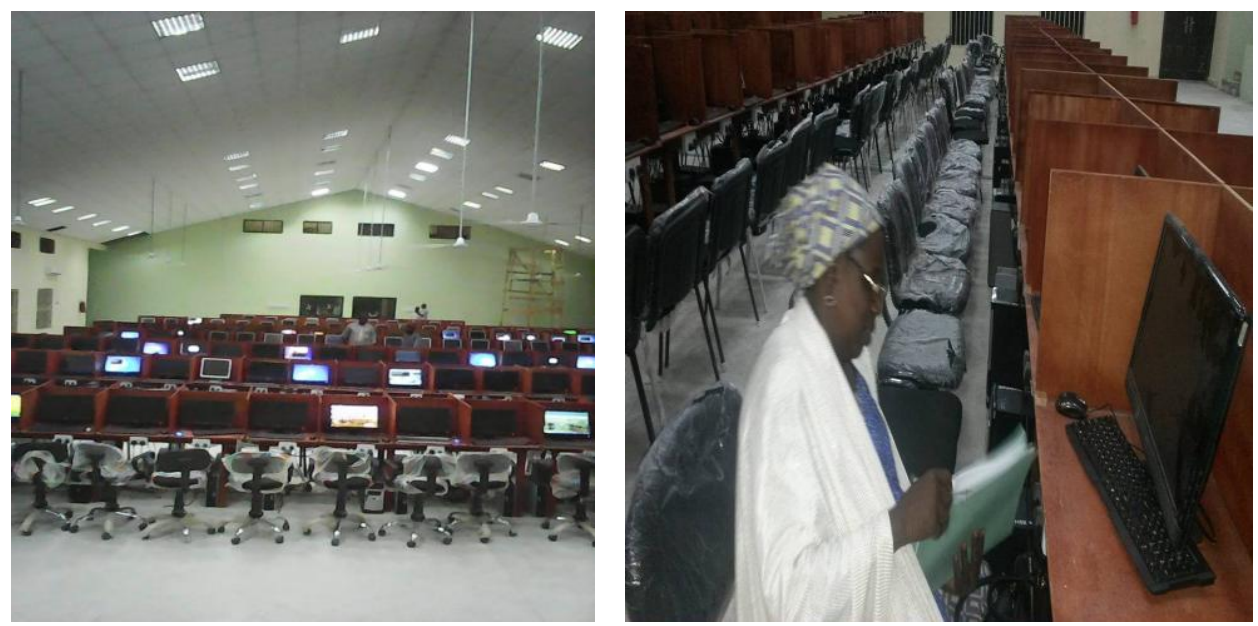

Figure 4. Newly Established Joint Admission and Matriculation Board (JAMB) Center Commissioned on $8^{\text {th }}$ September 2015.

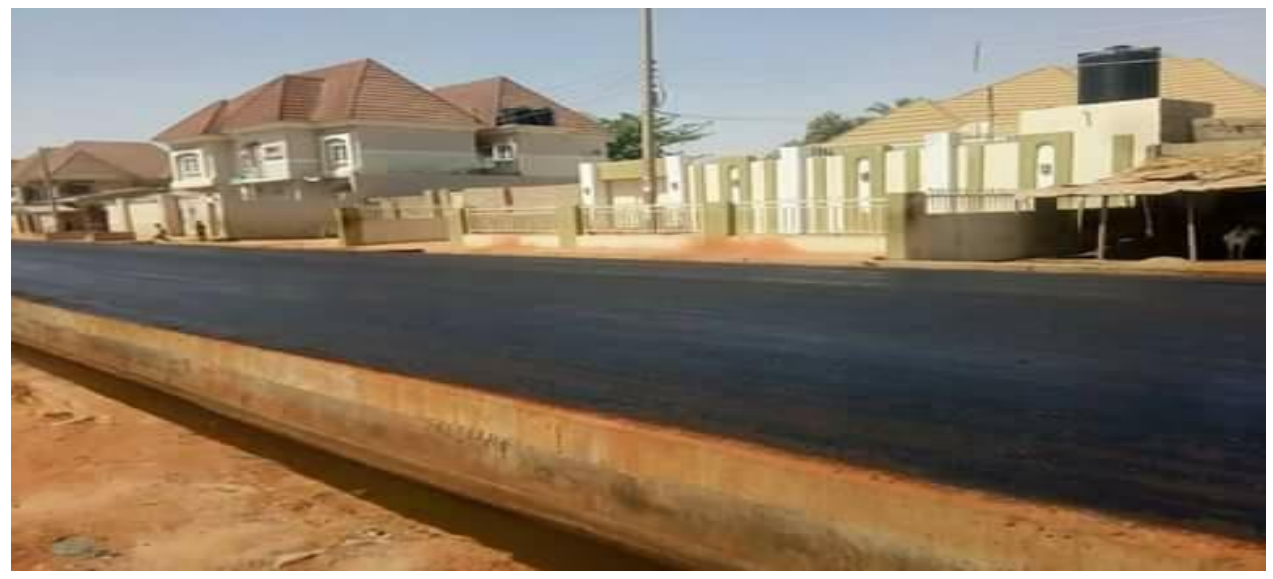

Figure 5. Newly Constructed Hadejia Town Ship Roads June 2018.

This is one of the newly constructed Hadejia township roads which HIMI claimed that the previous government refused to construct despite been enlisted among the roads already constructed.
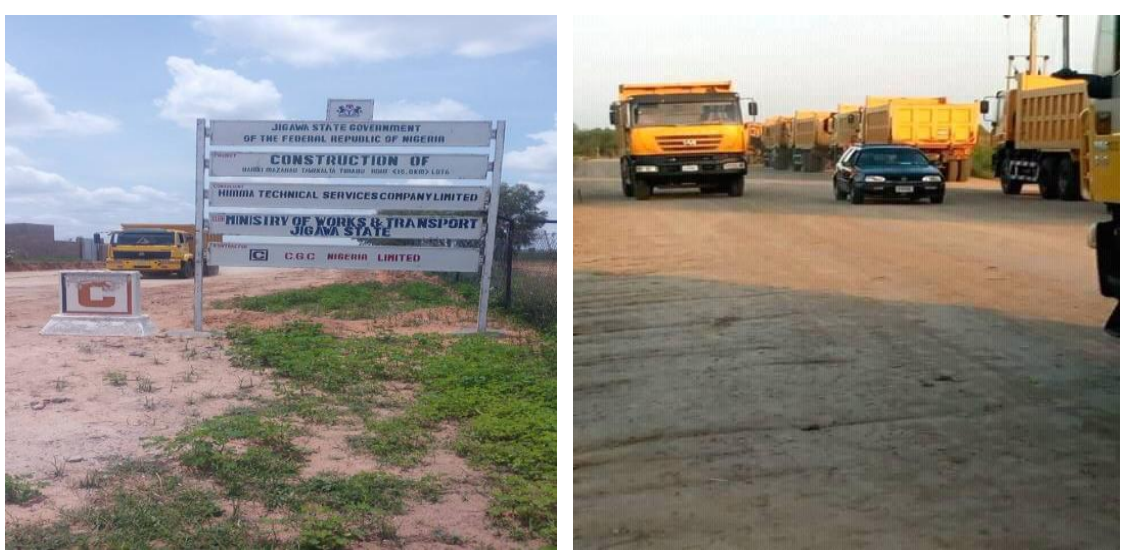

Figure 6. Hadejia, Garin Mutum Daya, Turabu Road Under Construction. 

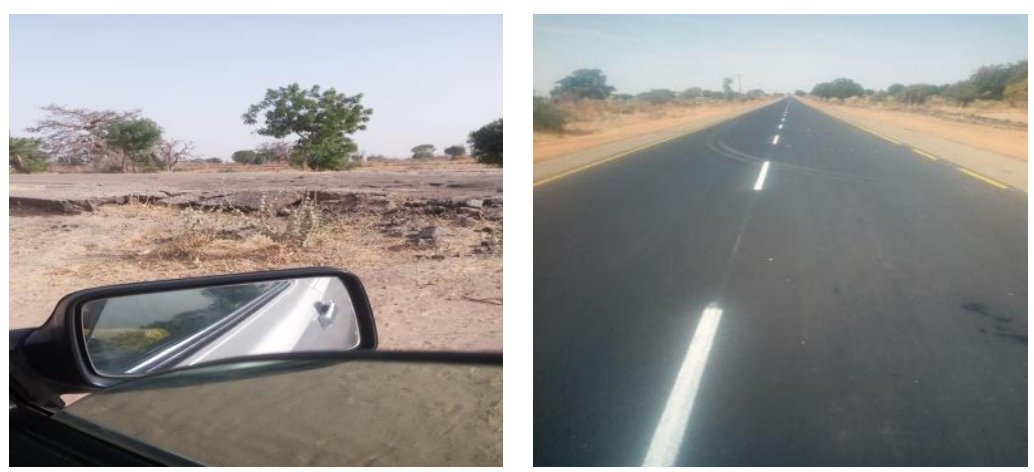

Figure 7. Old Dilapidated Kwanar Dundu, Bulangu Road 2015 Newly Re-constructed Kwanar Dundu Bulangu Road June 2018.

This is one of the abandon roads in the zone linking various villages to the ancient Bulangu District of Hadejia Emirate which was completely dilapidated but now has been reconstructed and commissioned.
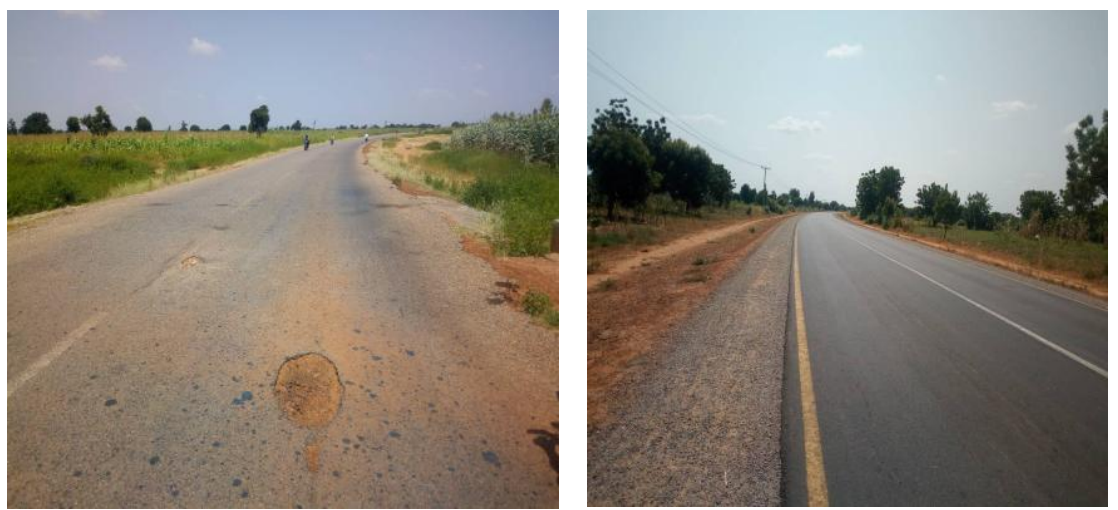

Figure 8. Old Dilapidated Tasheguwa- Road in 2015 Newly Renovate Tasheguwa-Guri Road 2018.

This is another road linking two local governments Kirikassamma and Guri LGAs. Some portion of the road was initially rehabilitated by the previous government but HIMI complained that the rehabilitation work was done carelessly without proper supervision and therefore dilapidated but now it was renovated and commission by the President of the Federal Republic of Nigerian.
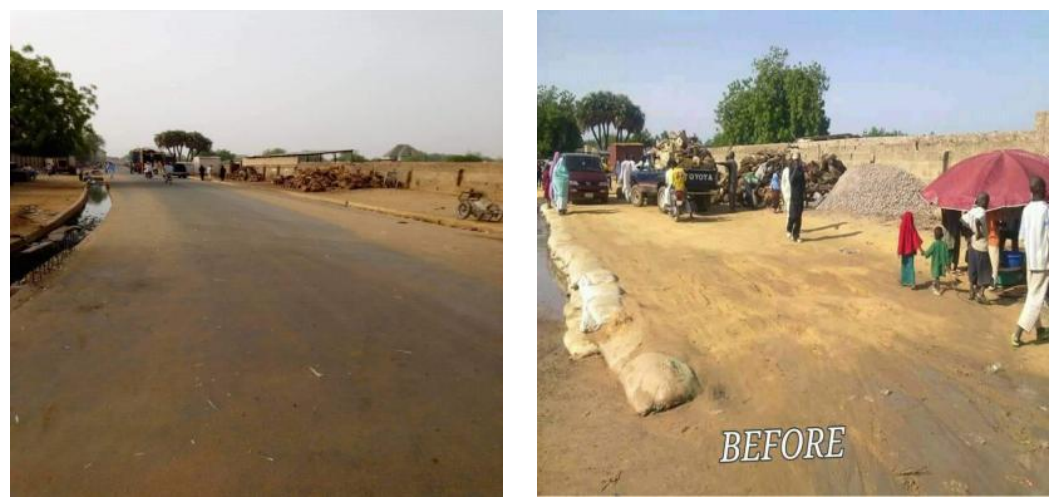

Figure 9. Newly Constructed Gawon Dogari Hadejia Township Road Old Gawon Dori Hadejia Township Road 2015. 


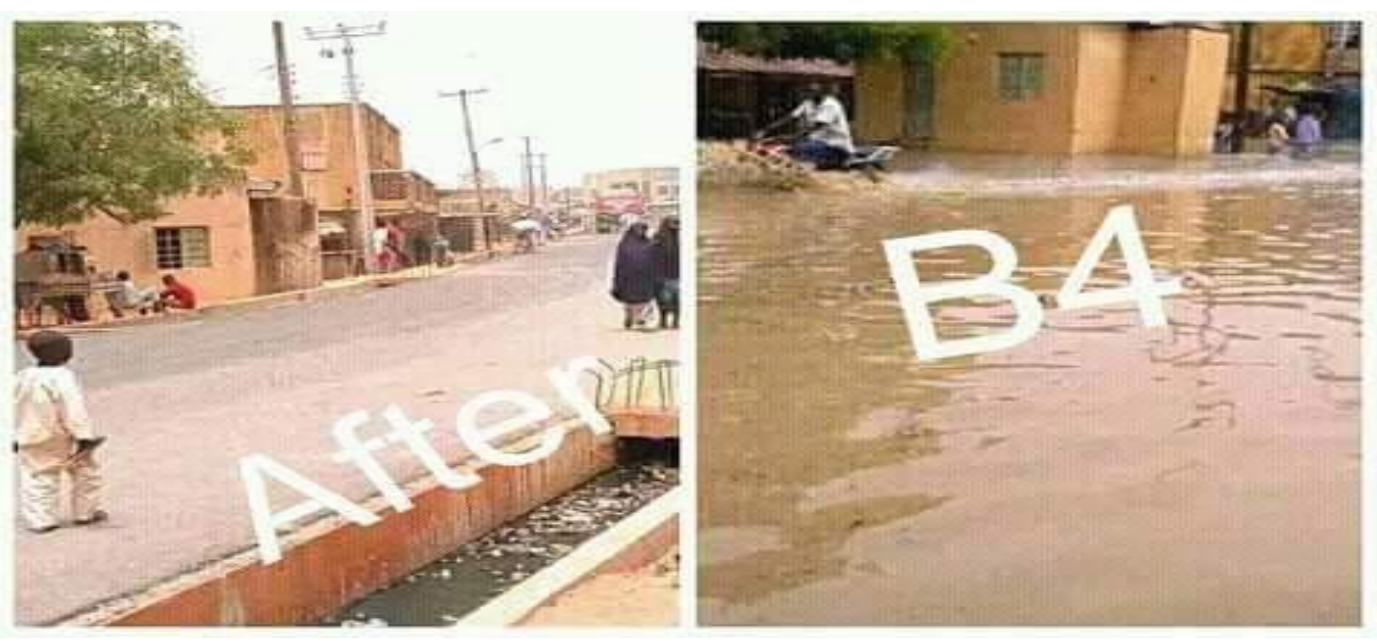

Figure 10. Same Road Constructed in 2018 Kuburu Road, Hadejia Flooded with Rain Water in 2015.

These pictures show the flooded areas of Dubantu and Yayari wards in the Hadejia City of Jigawa State. The pictures clearly show how bad the road was and how the local populace used to suffer for many years before it was constructed. Note that; both pictures were taken during the rainy season of 2015 and 2018.

\section{Youth and Women Empowerment through Skills Acquisitions}

Again, HIMI undertakes youth and women empowerment programs through skill acquisition and vocational training to the teaming unemployed youth of the zone. In 2016, the movement was able to train over 2000 youth in various vocational skills such as Tailoring, Bow-hole drilling, Carpentry, and woodwork across eight local government areas of the zone. Besides this, the movement in 2017 partnered with a renowned Chinese ICT Company (HUAWEI Technology) and trained 2,300 youths in 5 skills: ICT training, Shoe Making, Boreholes Drilling, GSM Repairs, Fish Farming, Cosmetics, and fashion design. Youths who want to apply for the Federal government (Npower Scheme) have been supporting by HIMI to do their free online registration also. Npower is the Federal Government youth employment policy to youths who graduate from University and some other tertiary institutions and not yet employed. The government provides them temporary employment with a monthly allowance. The movement has so far been able to register over 7000 youths across the zone. HIMI effort of creating support and opportunities to the youth in the zone, ICT facilities were provided by one of the Patrons of the movement in person of ( $\mathrm{Mu}$ hammad Babandede the Controller General of Nigerian Immigration Service, CGI) who donate over 30 computers and installed in the HIMI secretariat. This singular effort of the by the son of the emirate has attracted the Federal Governments agency (NITDA: the National Information Technology Development Agency) to resource the HIMIs secretariat with a Job creation center and e-learning facilities ( Jigawa State Government's News and Events, 2018, March, 26).

\section{Voluntary Educational Training Program}

Provision of voluntary lessons and Remedial classes to pre tertiary students who are deficient in their fields to enable them to make up the failed subjects and gain admission to the University are not excluded in the activities of HIMI. The movement renders computer-based (CBT) training also for the final year Secondary School students who applied for University and other Tertiary Institutions of learning and willing to write Joint Admission and Matriculation Board examinations (JAMB). For the past 3 years, a total number of 2,708 candidates have received CBT training by HIMI across the 8 local government areas of 
the emirate. Successful candidates who are able to pass the secondary school exams especially those from the rural areas are giving guidance and counselling assistance by HIMI in getting admission into the Nigerian Universities and other Tertiary institutions locally or abroad. Furthermore, HIMI also partner with the National Identity Management Commission (NIMC), signed MoU and assist the people of the emirate to register for the National Identity Card and acquire the National Identification Number (NIN). This effort makes many rural dwellers living in the hard to reach areas registered.

\section{Conclusion}

The paper outlined the role social movements and community-based organization play in bringing development to their areas. The struggle and tactics applied by Hadejia Ina Mafita Initiative, a community-based organization and Social Movement had clearly portrayed what a Social Movement should do in order to bring development to the marginalized area. HIMI identified the problems affecting their zone, planned for action through the outreach mobilization of the people to understand their motives and approached the government as a third sector between the government and the communities, they spoke on behalf of the communities and directly worked with the government to ensure the successful execution of the government projects in the area.

Social media platform (Facebook) was adopted as the medium of communication, and HIMI was able to reach and educate many people through weekly online seminar/advocacy. The movement also engaged in public lectures throughout the eight local government areas of the zone and was able to achieve their objective of unity and togetherness. The statistical facts and figures regarding unfair treatment and distributions of developmental projects Federal and State like (roads network, educational institutions, and health institutions) executed even before the creation of Jigawa State across the three senatorial districts are outlined. Similarly, the areas of the making of political appointments since the country's independence (1960) to the present situation were both presented to the government for equity and fairness. Fortunately, this coincided with the state government policy that is "Balanced Development" across the state.

The objectives identified on the targeted development were achieved through peace and dialogue. Presently the movement has embarked on other strategies to ensure inclusive growth and development. They engaged in youth and women empowerment through skills acquisitions and also partnering with Nongovernmental Organizations (NGOs) both National and International in their effort to empower their people to ensure poverty is reduced to the minimal. They also plan for voluntary educational programs to the rural populace of the zone which are in line with the United Nations Sustainable Development Goals (SDGs). The paper, therefore, recommends that other new social movement should copy HIMI strategist as a new model to achieve their objectives and targets. The paper also concluded by calling on international NGOs whose aim is to provide support for the poor to partner with HIMI and support the needy of Jigawa North East Senatorial Zone, Jigawa State and Nigeria in General. The paper only identified the achievement of HIMI in insuring Infrastructural development by the state government, but still more efforts need to put in place to ensure that the zone get the Federal Government attention to establish the Federal Educational Institutions they claim to be the only senatorial zone lagging behind in the distribution of such institution across Nigeria. Moreover, further research and academic debates need to be conducted to bridge the gap.

\section{References}

Advisory Group on Civil Society and Aid Effectiveness, (August 2008). Synthesis of Findings and Recommendations, Retrieved from http://web.acdi-cida.gc.ca/cs.

Ahmed, T. (2017). Strategy for Third State-Third Sector partnership for Sustainable Community Development in Nigeria; A Working Model. A Paper Presented at the $4^{\text {th }}$ National Community Development Consultative Conference/Workshop Organized by the International Association of Community Development (IACD) Nigeria. Bayero University, Nigeria.

Chechetto-Salles, M and Geyer, Y. (2006). Community-Based Organization Management. Handbook Series for Community-Based Organizations. The Institute for Democracy in South Africa (IDASA): Pretoria. 
Clark, E. (2012, June, 10). Social Media Is Our Media': Two Individual Activists' Perspectives of Their Relationship with the Uses of Traditional and Social Media during Occupy Wall Street. Retrieve from http://www.divaportal.org/smash/get/diva2:539573/FULLTEXT02.pdf.

Donk, W. D. et-al [Eds]. (2004). Cyberprotest: New Media, Citizens and Social Movements. London and New York, Routledge. Retrieved from https://disfasia.net/readings/cyberprotest.pdf.

Glasberg, D. S. \& Shannon, D. (2011). Political Sociology: Oppression, Resistance, and the State. California: Pine Forge Press, an Imprint of SAGE Publications.

Gloria. D. (2004). A History of the Social Development Network in the World Bank. Washington D. C.: The World Bank, Social Development, Paper No.56, March 2004.

Little, W. (2014). Social Movements and Social Change. Introduction to Sociology $-1^{\text {st }}$ Canadian Edition.

Midgley, J. (2014). Social Development: Theory and Practice. London: Sage Publications.

Neil Smelser's, N. J. (1963). Theories of Collective Behavior. New York: The Free Press.

Obar, A. J, Zube, P. \& Lampe, C. (2012). Advocacy 2.0: An Analysis of How Advocacy Groups in the United States Perceive and Use Social Media as Tools for Facilitating Civic Engagement and Collective Action. Journal of Information Policy, 2, 1-25. Retrieved from https://papers.ssrn.com/sol3/papers.cfm?abstract_id=1956352.

Sidney, T. S. (2005). The New Transnational Activist. Cambridge University Press: Cambridge.

Tilly, C. (2004). Social Movements, 1768-2004. Paradigm Press, Boulder; London

Tersoo, I. J., \& Ejue, E. A. (2015).Ethnic Militias and Insurgency in Nigeria: A Threat to National Development.International Journal of Humanities and Social Science, 5(2), 206-212.

United Nations Research Institute for Social Development (UNRISD), (2011). Social Development in an Uncertain World UNRISD Research Agenda 2010-2014. Retrieved from http://www.unrisd.org/research-agenda. 


\section{Appendix}
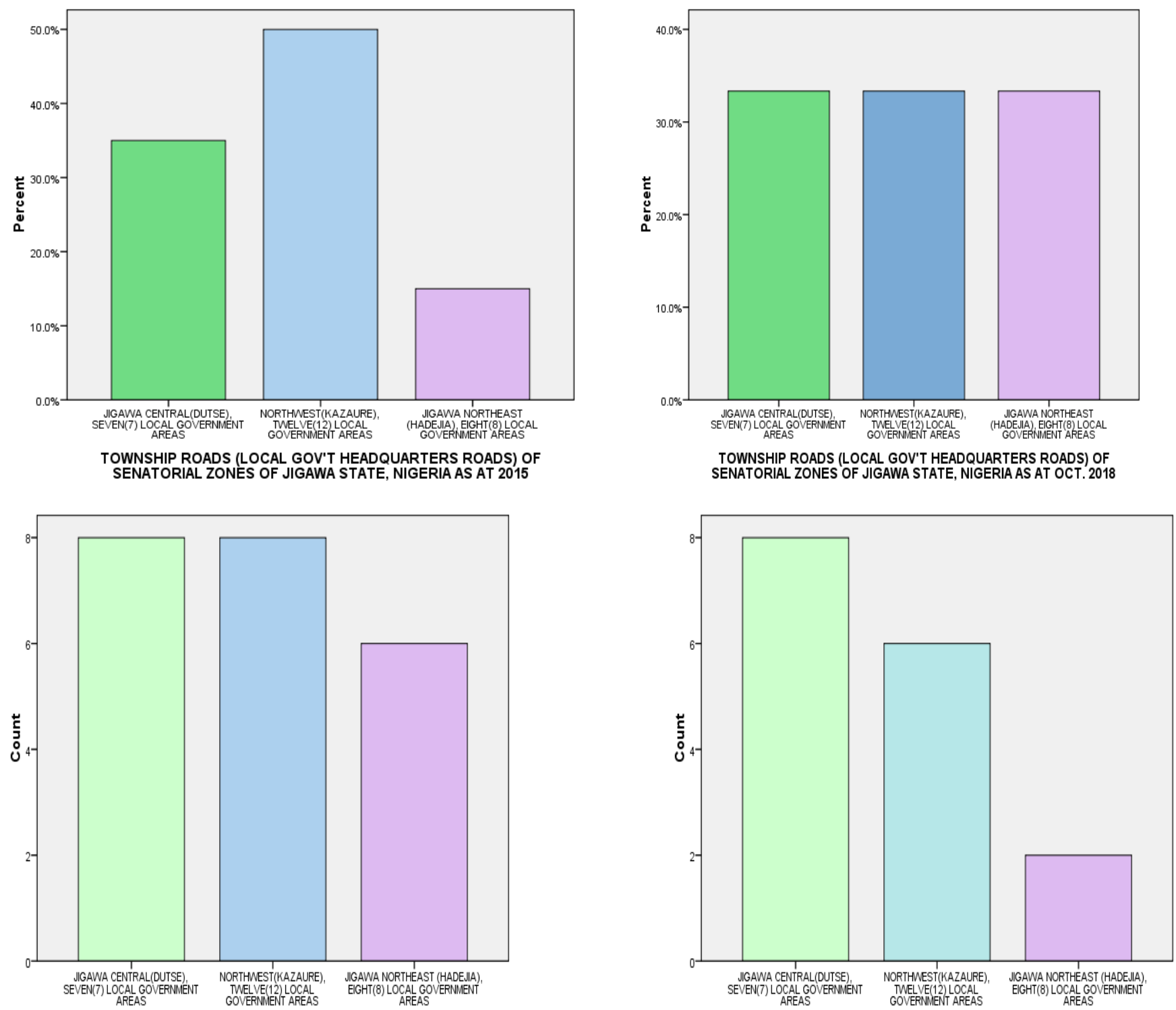

RENOVATED STATE ROADS OF SENATORIAL ZONES OF JIGAWA STATE, NIGERIA AS AT OCT. 2018

RENOVATED FEDERAL ROADS OF SENATORIAL ZONES OF JIGAWA STATE, NIGERIA AS AT 2015 


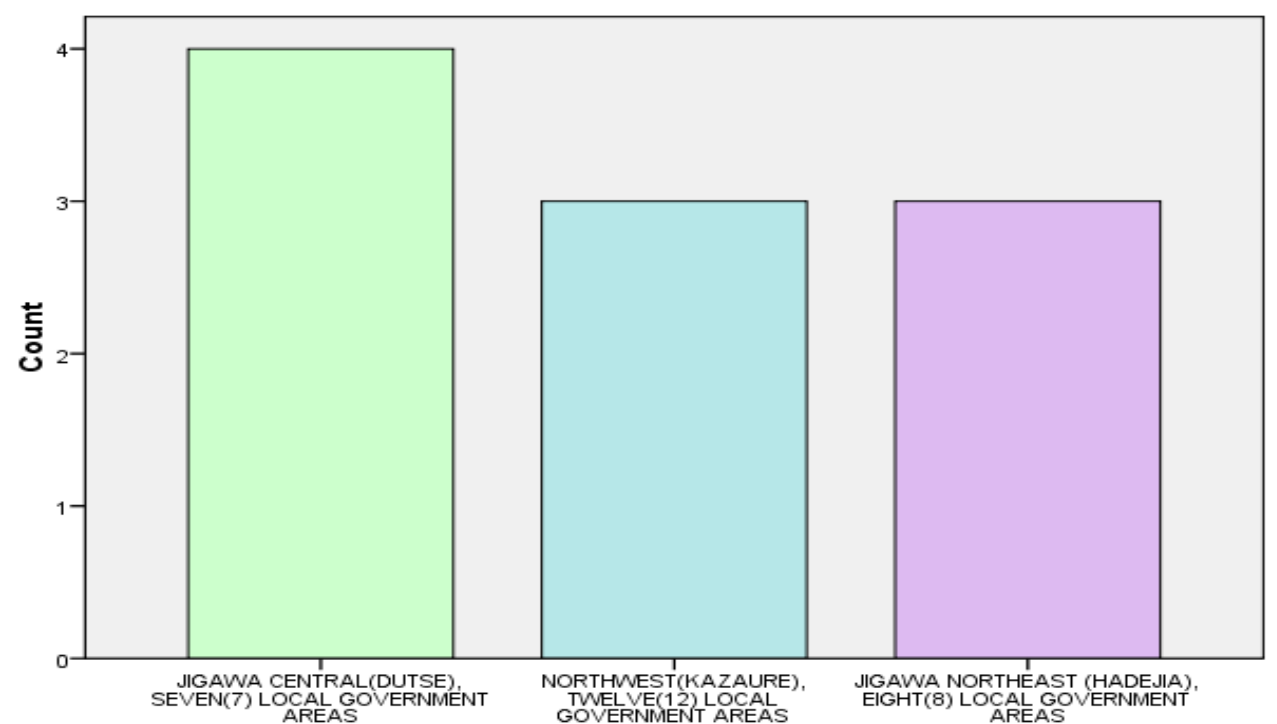

RENOVATED FEDERAL ROADS OF SENATORIAL ZONES OF JIGAWA STATE, NIGERIA AS AT OCT. 2018

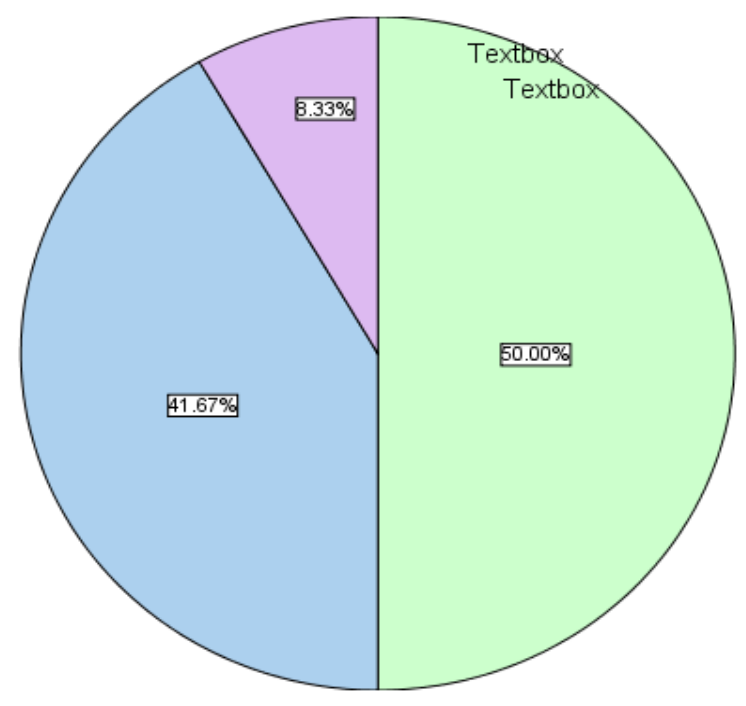

12 HOSPITAL OF

SENATORIAL ZONES

OF JIGAWA STATE

NIGERIA AS AT 2015

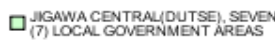

口 NORTHWEST/KAZAURE, TWEEVE

G IIGGWA NORTHEAST UHADEIAA. 

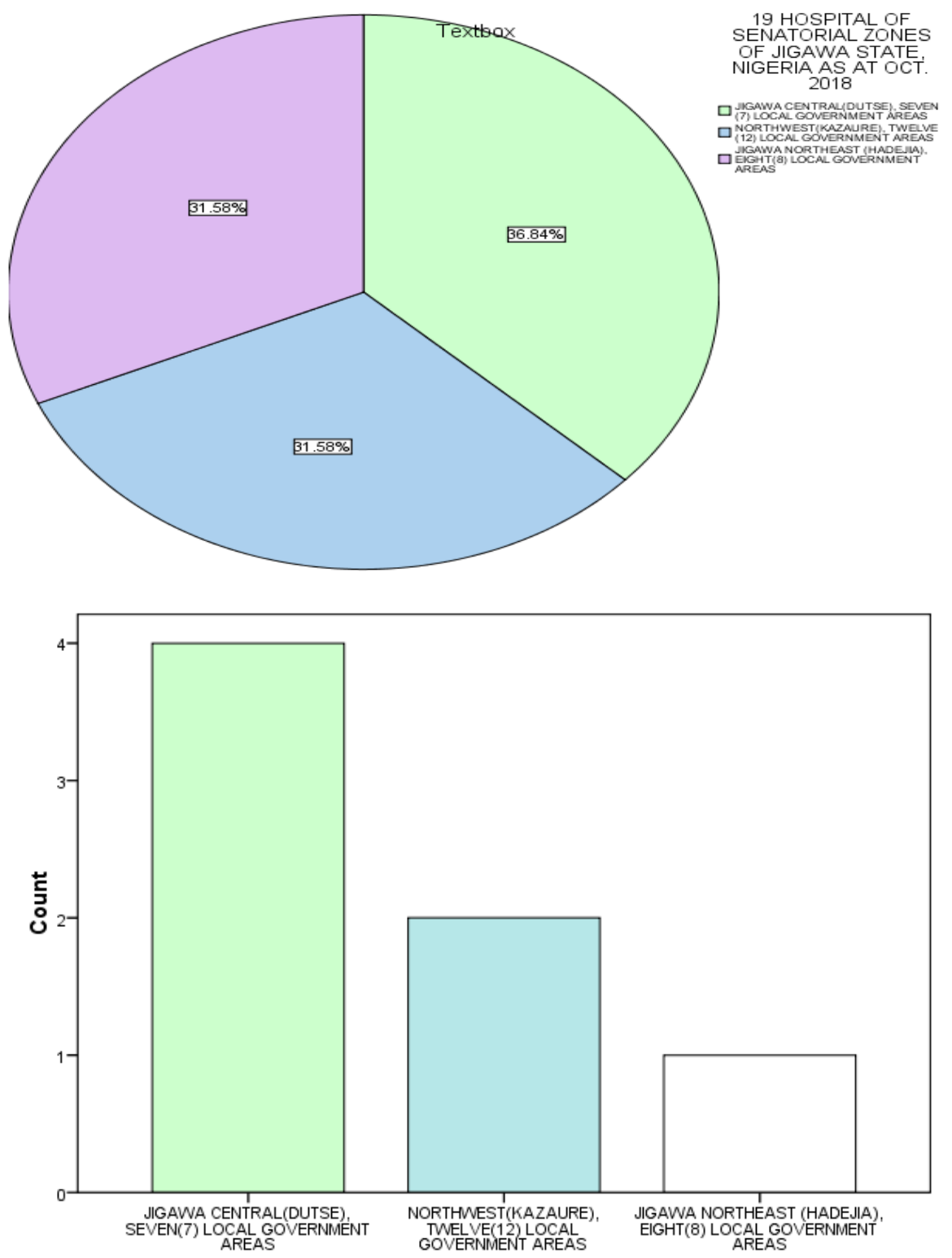

FEDERAL EDU. INSTITUTIONS OF SENATORIAL ZONES OF JIGAWA STATE, NIGERIA AS AT 2015/2018 

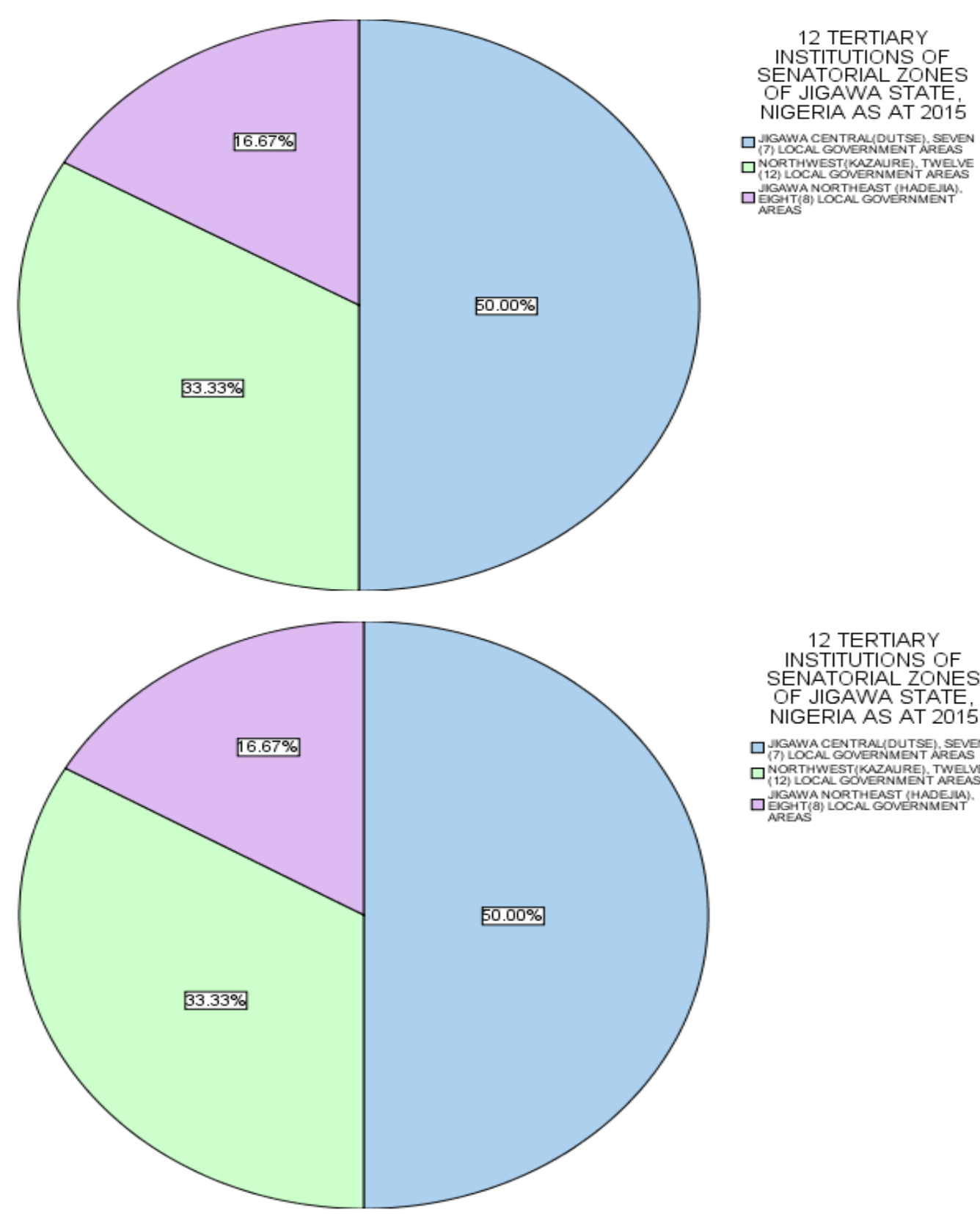

12 TERTIARY INSTITUTIONS OF SENATORIAL ZONES OF JIGAWA STATE, NIGERIA AS AT 2015

口 (7) LOCALENTRALIDUTSE) SEVEN

口 NORTHWEST/KAZAURE, TWELVE DIGAWA NORTHEAST (HADEIA.)
$\square$ EGGHT(B) LOCAL GOVERNMENT. AREAS 


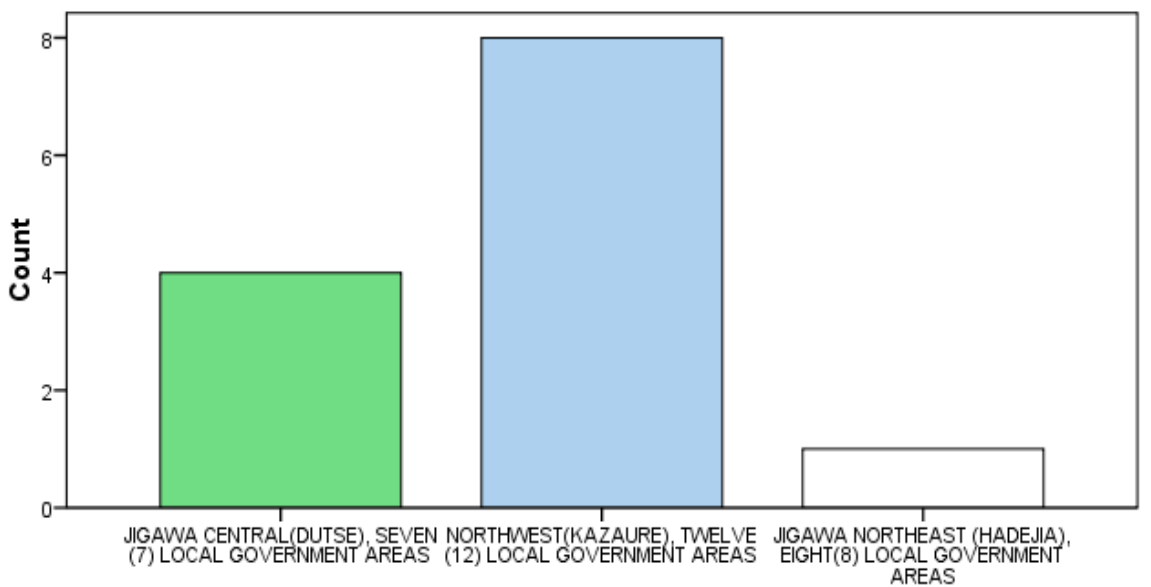

12 JAMB CENTERS OF SENATORIAL ZONES OF JIGAWA STATE, NIGERIA AS AT 2015

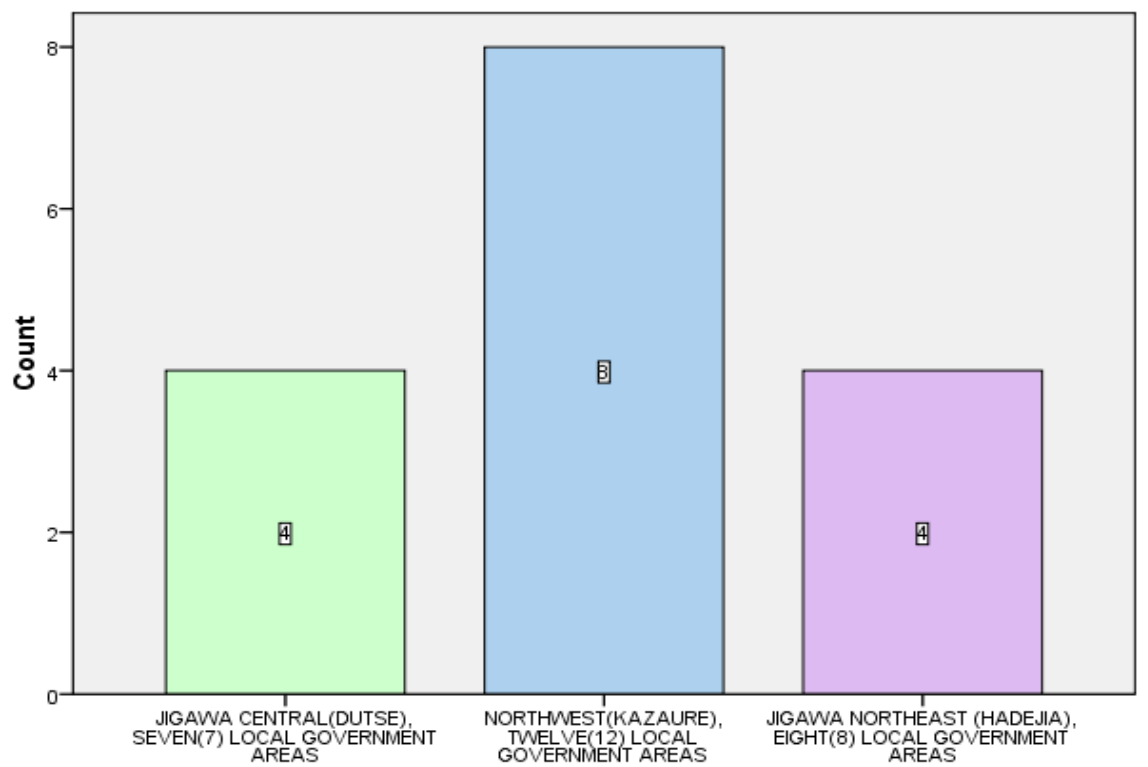

16 JAMB CENTERS OF SENATORIAL ZONES OF JIGAWA STATE, NIGERIA AS AT OCT. 2018 